\title{
Pendampingan Petani Gula Merah Sawit di Desa Roworejo Kecamatan Negeri Katon Kabupaten Pesawaran
}

\author{
${ }^{1}$ Kuswarak, ${ }^{2}$ Nuzleha, ${ }^{3}$ Yuliana Yamin, ${ }^{4}$ Abdilah Irwan Saputra \\ Fakultas Ekonomi Prodi Manajemen Universitas Sang Bumi Ruwa Jurai \\ Kuswarak23@gmail.com,Nuzlehahadjar1970@gmail.com,yuliyamin0607@gmail.com \\ Abdibedil040891@gmail.com
}

\begin{abstract}
Abstrak
Pohon sawit adalah salah satu suku palm yang sangat bermanfaat bagi kehidupan masyarakat pedesaan karena mempunyai nilai ekonomi tinggi karena hampir semua bagiannya dapat memberikan keuntungan finansial, sehingga jika dikelola dengan baik akan mampu bersaing. Berdasarkan hasil survey awal yang dilakukan oleh tim pengusul ke Desa Roworejo Kecamatan Negeri Katon banyak warganya sebagai petani sawit. Awalnya sawit hanya diambil buahnya pada saat panen yang langsung dijual ke pengepul. Seiringnya peningkatan SDM yang dimiliki warga maka melalui kelompok tani yang ada mereka mulai memanfaatkan pohon sawit selain dari buahnya, dengan membuat inovasi yaitu gula merah sawit dan jamur sawit. Di sini kami sebagai tim pengabdi mengambil salah satu dari usaha tersebut, yaitu gula sawitnya. Usaha yang ada sekarang adalah gula sawit padat, yang masih sangat sederhana dalam pengemasan maupun pemasarannya, sehingga pengabdi akan mengadakan pengabdian di desa tersebut dengan melakukan pendampingan kepada petani gula sawit dengan tujuan untuk peningkatan usaha gula sawitnya sehingga akan menambah pendapatan mereka. pendampingan yang akan dilakukan adalah melakukan pe nd a mp ing a n ke kelompok tani mitra bagaimana cara membuat Gula semut, pengemasan yang baik dan juga pola pemasaran. Metode yang digunakan untuk mencapai tujuan dan target tersebut adalah pendampingan tentang pengolahan nira sawit menjadi gula semut, pengemasan serta pola pemasarannya. Pendampingan dilakukan secara berkala dan berkesinambungan untuk lebih meningkatkan keterampilan petani mitra dalam pengolahan dari gula sawit, pengemasan yang menarik dan pola manajemen pemasaran. Hasil kegiatan pendamingan diharapkan menunjukkan kelompok tani mitra dapat meningkatkan produktivitas dan kualitas hasil dari nira sawit seperti gula semut dengan sentuhan teknologi sederhana proses pengolahan sampai proses pengemasan, sehingga dapat meningkatkan pendapatan kelompok tani mitra.
\end{abstract}

Kata Kunci : Gula Sawit, pendampingan, pemasaran

\begin{abstract}
The oil palm tree is one of the palm ethnic groups which is very beneficial for the life of rural communities because it has high economic value because almost all parts of it can provide financial benefits, so that if it is managed properly it will be able to compete. Based on the results of the initial survey conducted by the team of proposers to Roworejo Village, Negeri Katon District, many of the residents were oil palm farmers. Initially the fruit was only taken at harvest time which was directly sold to collectors. Along with the increase in human resources owned by the residents, through the existing farmer groups they began to use oil palm trees apart from the fruit, by making innovations, namely palm sugar and palm mushrooms. Here, as a service team, we take one of these businesses, namely palm sugar. The current business is solid palm sugar, which is still very simple in packaging and marketing, so that the servants will carry out community service in the village by providing assistance to palm sugar farmers with the aim of increasing their palm sugar business so that it will increase their income. The assistance that will be carried out is to provide assistance to partner farmer groups on how to make sugar ants, proper packaging and marketing patterns. The method used to achieve these goals and targets is assistance on processing palm sap into sugar, packaging and marketing patterns. Assistance is carried out regularly and continuously to further improve the skills of partner farmers in processing palm sugar, attractive packaging and marketing management patterns. The results of the cooling activities are expected to show that the partner farmer groups can increase the productivity and quality of the palm sap, such as ant sugar with a touch of simple technology from processing to packaging, so as to increase the income of partner farmer groups.
\end{abstract}

Keywords: Palm Sugar, assistance, marketing 
PENDAHULUAN

Pohon sawit sangatlah bermanfaat bagi masyarakat sebagai peningkatan ekonomi, tidak hanya itu saja tapi juga mendukung keberlangsungan lingkungan hidup. Hampir semua yang melekat di pohon sawit bisa diambil manfaatnya. Pohon sawit adalah salah satu anggota suku palm yang sangat bermanfaat bagi kehidupan masyarakat pedesaan karena mempunyai nilai ekonomi tinggi karena hampir semua bagiannya dapat memberikan keuntungan finansial, sehingga jika dikelola dengan baik akan mampu bersaing khususnya dengan jenis tanaman palma lainnya. Buah sawit yang kita ketahui adalah sebagai buah enghasil minyak sayur atau minyak kelapa.

Desa Roworejo Kecamatan Negeri Katon banyak warganya sebagai petani sawit. Awalnya sawit hanya diambil buahnya pada saat panen yang langsung dijual ke pengepul. Seiringnya peningkatan SDM yang dimiliki warga maka melalui kelompok tani yang ada mereka mulai memanfaatkan pohon sawit selain dari buahnya, dengan membuat inovasi yaitu gula merah sawit dan jamur sawit. Di sini kami sebagai tim pengabdi mengambil salah satu dari usaha tersebut, yaitu gula sawitnya. Pemanfaatan nira sawit oleh petani/masyarakat sebagai salah satu sumber pendapatan adalah gula merah cetak/padat, dari nira pohon sawit yang proses pengolahannya masih sangat tradisional dan belum ada usaha diversifikasi produk nira. Gula cetak dapat ditingkatkan mutunya dengan dibuat dalam bentuk dan kemasan yang lebih menarik, sehingga harga jual dan jangkauan pemasarannya lebih luas. Selain itu nira pohon sawit dapat juga diolah menjadi gula semut (palm sugar).

Berdasarkan hasil survey awal yang dilakukan oleh tim disimpulkan bahwa masyarakat di Desa Roworejo khususnya kelompok tani penyadap nira sawit belum memahami tentang diversifikasi produk nira lainnya dan pemasaran hasil pruduknya masih terbatas dan ditambah oleh para pedagang pengumpul yang hanya membeli dengan harga murah. Berdasarkan hasil diskusi dengan anggota kelompok tani mitra, maka produk nira sawit yang berpotensi untuk dikembangkan sebagai produk unggulan lokal daerah adalah gula padat dan gula semut yang bernilai ekonomi.

Gula semut merupakan produk nira sawit yang berbentuk gula merah kristal yang sangat unggul untuk digunakan sebagai bahan pangan dan berefek fungsional bagi kesehatan. Kelebihan gula semut adalah memiliki aroma khas yang merangsang selera, bentuk karamelnya bertekstur halus dan lembut, sehingga penyerapan glukosa berlangsung lambat sehingga menurunkan kadar gula darah pada penderita diabetes, tidak menyebabkan obesitas atau kegemukan, proses pengolahannya tidak menggunakan bahan kimia sehingga lebih aman untuk dikonsumsi dan membantu terbentuknya energi, memperbaiki kerusakan sel saat proses produksi energi, dan memperbaiki jaringan sistem pencernaan.

Usaha ini belum mendapat perhatian dari pemerintah setempat misal bagaimana upaya meningkatkan keterampilan dan mencari produk-poduk unggulan lokal daerah dari nira sawit. Persoalan yang dihadapi oleh mitra dalam pengembangan produk nira sawit diantaranya teknik penyadapan nira yang belum menghasilkan nira bersih, proses pengolahan nira pohon sawit belum bisa memproduksi gula semut, proses pengemasan gula cetak masih sederhana dan pola pemasaran gula belum efektif dan berkembang serta belum ada bantuan pembiayaan.

Permasalahanya adalah masyarakat harus lebih bisa menfaatkan nira sawit unutk komoditas ekonomi. Pengetahaun masyarakat tentang nira sawit masih sangat minim ini masih perlu ditingkatkan, sehingga menjadi gerakan bersama untuk meningkatkan nilai ekonomi masyarakat. Keseriusan dalam mengolah nira sawit menjadi komoditas ekonomi maka yang dapat dilakukan dengan memanfaatkan nira sawit menjadi berbagai produk, diantaranya menjadi gula merah sawit padat, gula semut sawit, dan lain sebagainya. Selain digunakan 
sebagai bahan baku pembuatan gula, nira juga digunakan sebagai bahan baku asam cuka, minuman segar, dan minuman keras (tuak).

Program Pengabdian Kepada Masyarakat yang dilaksanakan saat ini, lebih mengarah bekerja sama dengan kelompok tani atau masyarakat mengangkat tema "Pendampingan Petani Gula Merah Sawit di Desa Roworejo Kecamatan Negeri Katon Kabupaten Pesawaran”

\section{METODE PELAKSANAAN}

Kegiatan ini pada dasarnya merupakan kegiatan dalam bentuk pendidikan kepada masyarakat. Bentuk yang dipilih adalah pelatihan yang dilanjutkan dengan pendampingan. Metode yang digunakan adalah persuasive - edukatif - komunikatif - partisipatif. Untuk itu akan dikembangkan prinsip nilai manfaat yang sesuai dengan pengalaman, praktis, menarik, partisipasi aktif, dan kemitraan. Maka akan dilakukan langkah solusi atas persoalan yang disepakati bersama berupa kegiatan:

Untuk lebih meningkatkan keterampilan kelompok petani sawit dalam hal penyadapan nira, proses pembuatan gula semut, pengemasan dan pemasarannya, maka dilakukan kegiatan pendampingan. Selain itu juga dilakukan evaluasi secara periodik untuk keterampilan penguasaan teknologi pengolahan gula semut dan pola manajemen usaha sehingga kegiatan ini dapat berkelanjutan dan pada akhirnya terbentuk masyarakat yang mampu melakukan usaha mandiri.

Tempat pengabdian masyarakat ini dilaksanakan di Desa Roworejo Kecamatan Negeri Katon Kabupaten Pesawaran. Adapun pelaksanaan aktivitas pengabdian kepada masyarakat melalui program pendampingan bagi petani sawit dilakukan dengan tahap-tahap sebagai berikut: pendampingan dalam produksi gula semut, pengemasan produk, dan pemasaran. Untuk mengukur keberhasilan penerapan pendampingan, terdapat dua indikator tujuan terukur dalam jangka panjang yaitu: menghasilkan produk berupa gula semut, produk yang dipasarkan dapat diterima oleh masyarakat, memiliki usaha yang berkesinambungan guna meningkatkan pendapatan ekonomi masyarakat di Desa Roworejo.

\section{HASIL DAN PEMBAHASAN}

Hasil yang diperoleh selama kegiatan Pengabdian adalah sebagai berikut.

\section{Pelatihan Pengolahan Nira sawit menjadi Gula Semut}

Sebelum melakukan program inti, tim pengabdi melakukan obeservasi awal sebagai tindakan pertama untuk melaksankan kegiatan. Observasi yang dilakukan adalah mencari tahu dimana saja tempat yang memiliki pohon sawit, yang biasa membuat gula merah. Pelatihan kegiatan pengabdian masyarakat dilaksanakan di Desa Roworejo Kecamatan Negeri Katon Kabupaten Pesawaran, tim pelaksanan yang memberikan pelatihan tentang pembuatan gula pohon sawit baik gula pohon sawit dalam bentuk padat maupun gula semut, dilanjutkan dengan rapat koordinasi dengan mitra mengenai jadwal pelaksanaan kegiatan yang akan dilaksanakan selama kegiatan baik alat dan bahan yang dipersiapkan oleh tim maupun oleh mitra dan sebagainya. Tim pengabdi membeli bahan nira untuk praktek, menyiapkan cetakan, plastik aluminium untuk kemasan.

Mitra menyiapkan alat-alat dan beberapa bahan yang diperlukan selama kegiatan pelatihan yaitu wajan, kompor gas, alat pengaduk, pengayak serta menyiapkan tempat dan waktu pelatihan. Tim menyiapkan peralatan yang tidak dimiliki oleh mitra. 
Hal yang paling sulit saat pertama kali pembuatan gula pohon sawit padat adalah memastikan waktu yang tepat untuk pendinginan setelah adonan nira yang matang kemudian diangkat dan dituang pada cetakan membuat cairan nira mengkristal atau membeku. Selama ini para petani nira membuat gula sawit dengan bentuk yang konvensional yaitu nulat dari potongan pohon bambu sehingga bentuk gula yang dihasilkan tidak sama dan tanpa kemasan sehingga harga jual dipasar tidak stabil dan kurang menarik. Sehingga tim mempunyai pemikiran untuk pembuatan cetakan gula adat yang menghasilkan gula merah sawit padat yang sama ukurannya.Dalam kegiatan pengabdian masyarakat ini juga, dilaksanakan pelatihan pembuatan gula semut. Gula semut yang dihasilkan dibuat dengan cara sama seperti pembuatan gula pohon sawit padat hanya yang berbeda adalah pada saat pencetakan terakhir. Pembuatan gula semut ini dilakukan dengan maksud untuk membuat inovasi baru yakni dalam bentuk serbuk. Para petani sawit ini tertarik untuk membuat gula semut, karena peluang gula semut dipasaran sangat potensial dan banyak peminat terutama untuk bidang usaha produksi kue dan pangan di pabrik, hotel, restoran, kafé dan lain-lain.

\section{Pembuatan Gula Semut}

\section{Alat dan Bahan:}

Kain bersih, Kuali atau panci, Tungku, Nira pohon sawit, Air bersih, Pengayakan, Garpu kayu, Kantong palstik dan Labeling.

\section{Cara Kerja:}

1. Saring nira dengan kain bersih

2. Setelah disaring, nira segar dipanaskan selama 3 jam. Api tidak boleh terlalu besar agar tidak gosong, tapi juga tidak terlalu kecil.

3. Proses pembuatan gula semut mendekati akhir jika cairan nira manis itu mulai mengental. Indikasinya kalau diteteskan kedalam air terlihat seperti benang dan tidak terputus.

4. Setelah itu kuali diangkat dari tungku

5. Setelah diperoleh nira kental dilanjutkan dengan pendinginan dan pengkristalan.

6. Pengkristalan dilakukan dengan cara pengadukan menggunakan garpu kayu. Pengadukan dilakukan secara perlahan-lahan, dan makin lama makin cepat hingga terbentuk serbuk gula (gula semut).

7. Langkah selanjutnya adalah pengeringan gula semut. Pengeringan dilakukan dengan cara, yaitu pengeringan dengan sinar matahari selama 3-4 jam.

8. Untuk keseragaman ukuran butiran, dilakukan pengayakan. Butiran gula yang tidak lolos ayakan akan dikeringkan ulang dan dilanjutkan dengan penghalusan butiran dan dilakukan dengan pengayakan yang kedua.

9. Gula semut kering dikemas dalam kantong plastik dengan ukuran berat bervariasi, yaitu $250 \mathrm{~g}, 500 \mathrm{~g}$ dan $1000 \mathrm{~g}(1 \mathrm{~kg})$

\section{Pelatihan Pengemasan Gula Merah Padat Dan Gula Semut}

Salah satu indikator penentu laris atau tidaknya suatu produk selain kualitas rasa dan orisinalitas adalah kemasan yang menarik. Selama ini mitra menjual gula pohon sawit dalam 
bentuk padat dan ditimbang serta dihitung dalam kiloan kemudian dimasukkan kedalam peti yang berisi $10 \mathrm{~kg}$ yang sudah dilapisi dengan pelastik tanpa kemasan dan pembungkus khusus gula pohon sawit, sehingga hygiene sanitasi atau kualitas produk masih sangat minim. Oleh karena itu harga jualpun tidak stabil dan cenderung lebih murah. Melihat fenomena ini, tim pelaksana pengabdian memberikan pelatihan dalam proses pengemasan gula sawit dengan menggunakan kemasan yang menarik dan diberi label sehingga harapannya bisa menarik bagi konsumen dan dapat meningkatkan nilai penjualan.

\section{Pelatihan Pemasaran Gula Merah Padat Dan Gula Semut}

Pelatihan dan praktek ini kami berikan dan persiapkan untuk petani gula sawit dengan menggunakan perangkat komputer atau laptop atau menggunakan media sosial.

Tim pengabdian sudah melakukan survey awal terhadap beberapa supermarket atau toko dan beberapa tempat sasaran yang dapat dijadikan tempat kerjasama dan menawarkan produk. Tujuan survey dan pendekatan adalah memberikan tawaran atau beberapa contoh tempat yang dapat dijadikan sasaran untuk memasarkan produk gula sawit. Sehingga mitra memiliki bayangan dan minimal memiliki pengetahuan mengenai alur dan mekanisme dalam menawarkan produk ke suatu pasar modern, dan toko. Selain itu tim pengabdi juga memberikan pelatihan cara pemasaran online dengan media sosial dan sebagainyasehingga diharapkan pemasaran gula sawit tidak hanya lokal di daerah Pesawaran saja tapi bisa menjangkau daerah yang lebih jauh lagi.

Khalayak sasaran kegiatan pengabdian ini adalah petani sawit sebagai mitra yang berlokasi di Desa Roworejo Kecamatan Negeri Katon Kabupaten Pesawaran. Dalam program kegiatan ini difokuskan untuk pembuatan gula semut, pengemasan dan juga pemasarandengan harapan mempunyai nilai ekonomi lebih tinggi dibandingkan dengan hanya gula padat.

Kegiatan ini merupakan Program hibah internal Universitas Sang Bumi Ruwa Jurai dengan tim pengabdi terdiri dari dua (3) orang dosen yang bergelar akademik S2, dan satu (1) orang mahasiswa yang berasal dari Fakultas Ekonomi Jurusan Manajemen..

Pelaksanaan kegiatan dikoordinasikan dengan petani gula sawit, Kepala Desa. Metode pendekatan yang digunakan meliputi pelatihan, dan pendampingan. Materi pelatihan yang dilakukan diantaranya cara pembuatan gula semut yang sistematik sehingga nilai gizi dan efek fungsional terhadap kesehatan tetap terjaga dan cara pengemasan gula sawit dan gula padat yang baik sehingga lebih menarik dan daya simpannya lama., dan juga pola emasaran yang lebih baik lagi. Pelaksanaan pengabdian ini secara umum berjalan lancar dan baik serta tidak menemui kendala ini dilihat dari antusias para petani gula sawit.

Pendampingan dilakukan secara periodik dengan tujuan memantau perkembangan produksi palm sugar di lokasi mitra supaya tetap berkelanjutan. Sehingga dengan adanya progran pengabdian ini dapat meningkatkan pendapatan kelompok tani. Untuk keberlanjutan program maka diperlukan peran aktif petani gula untuk tetap memproduksi gula padat, gula semut dan pemasaran ditingkatkan.

\section{KESIMPULAN}

Pelaksanaan pengabdian ini telah berjalan sesuai rencana dan tujuan awal yaitu memberikan pelatihan atau pendampingan mengenai produksi gula sawit padat serta gula semut atau dalam bentuk serbuk, pelatihan pengemasan produk serta membuat design label untuk produk gula sawit, memberikan pelatihan mengenai hygiene sanitasi dan pola pemasaran. Pelaksanaan kegiatan ini d i h a r a p k a n dapat meningkatkan pengetahuan dan keterampilan petani gula sawit dalam hal diversifikasi produk gula sawit khususnya tentang pengolahan nira sawit menjadi gula semut. Selain tim pengabdian yang memberikan pendampingan. Kegiatan ini mendapat respon positif dari petani gula sawit dan didukung penuh oleh Kepala Desa 
Roworejo. Luaran yang dihasilkan adalah artikel, produk gula sawit padat dan gula semut yang sudah dikemas, desain label kemasan serta pemasaran online dan bermitra dengan toko atau swalayan.

\section{UCAPAN TERIMA KASIH}

Terima kasih penulis ucapkan kepada semua pihak yang telah membantu pelaksanan kegiatan pengabdian kepada masyarakat diantaranya:

1. Universitas Sang Bumi Ruwa Jurai dan LPPM yang telah turut serta memberikan kesempatan kepada tim pengabdi untuk melaksanakan pengabdian di Desa Roworejo.

2. Bapak M. Sugiono, S.E. selaku Kepala Desa Roworejo

3. Petani gula sawit di Desa Roworejo Kecamatan Negeri Katon Pesawaran

\section{DAFTAR PUSTAKA}

Burhanudin. 2005. Prospek Pengembangan Usaha Koperasi Dalam Produksi Gula pohon sawit. Jakarta.

Farida, Yayuk \& Ali Khompsan. 2006. Pengantar Pangan \& Gizi. Penebar Swadaya: Jakarta.

Soekartawi. 2005. Agribisnis Teori dan Aplikasinya. PT. Raja Grafindo Persada. Jakarta

Soleh, A. D. 2009. pohon sawit, Sumber Energi Alternatif. Pusat Penelitian dan Pengembangan Tanaman Perkebunan. Bogor.

Pohon, J., dan Audy W. 2014. Perbaikan Proses Pembuatan Gula erah pohon sawit di Pabrik Gula Aren Masarang Tomohon. Jurnal MIPA UNSRAT Online 3 (2) 68- 73. 